\title{
APŠVIETIMAS KAIP ARCHITEKTŪROS MODERNUMO SIMBOLIS
}

\author{
Martynas Valevičius \\ Architektūros pagrindu ir teorijos katedra, Vilniaus Gedimino technikos universitetas, \\ Pylimo g. 26/Traku g. 1, LT-01132 Vilnius, Lietuva, \\ El.paštasmartynas@valevicius.com
}

Iteikta 20090504

Santrauka. Straipsnyje nagrinejjama dirbtinio apšvietimo estetika ir jos ịtaka XX a. architektūrai. Išryškinta XIX a. pabaigoje atsiradusio elektrinio apšvietimo svarba ir atskleista apšvietimo techninè raida iki XX a. vidurio. Nagrinejjamos dirbtinio apšvietimo sąsajos su vizualiaisiais menais, apšvietimo įtaka reklamai, pastatų architektūrai bei visam miestui. Straipsnyje keliama idèja, kad nors apšvietimo prigimtis pradžioje buvo grynai funkcionali, ji greitai ịgavo simbolinių ambicijų - reprezentuoti architektūrą. Architektai ị apšvietimą žvelgè ne tik kaip ị technologinę pažangą, tai buvo naują erą ženklinantis simbolis, erą, kurioje atsiranda didelès ịtakos visoms kūrybinèms idèjoms turinti nauja savarankiška kūrybos sritis - šviesos architektūra.

Reikšminiai žodžiai: meninis, dirbtinis, elektrinis apšvietimas, stiklo, šviesos architektūra, modernumas.

\section{İvadas}

$\mathrm{XX}$ a. pradžios architektūrą nagrinèjo ne vienas architektūrologas, tačiau vis dar galima atrasti naujų nepakankamai ištirtų šio laikotarpio, kuriuo vyko kultūrinès ir socialinès visuomenès transformacijos bei sparti mokslo ir technikos pažanga, architektūros meninès raiškos klausimų. Vienas iš progresą inspiravusių veiksnių buvo vis platesnis elektros taikymas, labiausiai atkreiptinas dèmesys ị elektros šaltinių generuojamą šviesą. Šviesos fenomenas siejamas su daugeliu ezoterinių ir psichologinių prasmių, kurių šiame straipsnyje nesiekiama atskleisti, taip pat nebandoma išsamiai aprašyti visos dirbtinio apšvietimo istorijos, bet norima atkreipti dèmesị $\mathfrak{i}$ tai, kad architektūros modernumą apibūdinantys bruožai - naujumas, pažanga, mokslo ir technikos naujovių taikymas (ir kiti) - labai tinka apibūdinti dirbtiniam apšvietimui. Apšvietimas visuomet atrodo naujai, galbūt dèl to kai kurie apšvietimo taikymo būdai per XX a. buvo kelis kartus pristatomi visuomenei kaip naujausias technikos ir mokslo atradimas, nepaminint ankstesnių pasiekimų (Neumann 2002). Tačiau per XX a. apšvietimas labai išplito ir žmonès prie jo greitai priprato, šviesos miestuose tapo tiek daug, kad šis reiškinys nebekelia jokios nuostabos. Šviesą deramai ịvertinti galima tuomet, kai yra pakankamai tamsos, kai yra su kuo palyginti, tada apšvietimas atsiskleidžia visu savo grožiu (Jakle 2001). XX a. pirmoje pusèje šviesos dar nebuvo per daug ir jau buvo žinomi beveik visi iki šių dienų naudojami šviesos šaltiniai, kai kurie iš jų dèl ịvairių priežasčių (patentai, ekonominès sąlygos) plačiai taikyti pradèti tik pastaruoju metu. Šiame straipsnyje norima išryškinti didelę dirbtinio apšvietimo meninę įtaką architektūrai, nes dirbtinè šviesa leido „prailginti dieną" - tai pakeite darbo režimus, laisvalaikio būdus, sukūrè savitą naktinį gyvenimą su savita naktine šviesos architektūra.

Modernumo sąvoka aprèpia daugelį avangardinių meno krypčių su begale revoliucingų idejjų, padariusių ịtaką vèlesnei architektūros raidai, tačiau ne visos jų skyrẻ dėmesio dirbtiniam apšvietimui. Nors iš darbų galima pajusti, kad savito santykio su šviesa ieškojo daugelis menininkų ir architektų, ne visi jų išskyrė dirbtinès šviesos suteikiamas galimybes. Le Corbusier, vienas iškiliausių modernizmo architektų, pastebejjo, kad šviesa ir architektūra egzistavo kartu nuo civilizacijos aušros, kad nèra jokios architektūros be šviesos. 
Architektūra yra meistriškas, teisingas ir nuostabus formužaidimas šviesoje (Le Corbusier 1923). Le Corbusier entuziastingai domejjosi inžinerinėmis ir technikos naujovèmis, statybų technologijomis, tačiau kalbėjo tik apie natūralią saulès šviesą, o meniniam apšvietimui dèmesio neskyrè. Meninio apšvietimo svarba mažai tyrinèta ir architektūrologų. R. Banham rašè: Visa architektūros istoriku karta ignoravo viena sensacingiausiu ir tuo pačiu metu viena iš pastebimiausiu praejusio šimtmečio atradimu ir svarbiausia visiškai negebejo vertinti jo pasekmiu. N. Pevsner, S. Giedion ir H. R. Hitchcock parašè savo darbus elektros amžiuje ir nematè bütinybès jivvertinti dirbtinès šviesos reikšmès architektūrai (Banham 1988).

Šis straipsnis yra platesnio tyrimo apie miestu meninio apšvietimo raida ir nūdienos tendencijas dalis, todèl jame siekiama apžvelgti tik tas architektūros modernumą simbolizuojančias idejjas, kurios aiškiai deklaravo savo sąsajas su apšvietimu; tikslas yra atskleisti meninio apšvietimo raidą XX a. pirmoje pusèje ir nustatyti pagrindinius meninio apšvietimo konceptus bei jų kilmę.

\section{Dirbtinio apšvietimo techninè raida}

Iki XVIII a. pasaulyje buvo žinomi du šviesos šaltiniai: dienos šviesa, prie kurios akys prisitaike per keletą milijonų metų, ir ugnis, kurią žmogus ịvalde akmens amžiuje. Ugnis - pirmasis dirbtinès šviesos šaltinis. Nusileidus saulei miestai paskęsdavo tamsoje. Net didžiausių Europos miestų gyvenimas sutemus apmirdavo. Iki XVII a. pabaigos jokio gatvių apšvietimo nebuvo. Priešingai, bijant gaisrų, griežtai drausta palikti be priežiūros degančius žibintus. Iš rotušès bokšto būdavo stebima, ar po vakarinių varpo dūžių nešviečia kur žiburys. Tada siųsdavo tvarkdarị isspèti. Miestelènai kelią pasišviesdavo tik nešiojamais žibintais. 1602 m. dokumentuose užsimenama apie žibintus prie Vilniaus Žemutinès pilies sienų, krantinèje. Tikètina, kad jie buvo ịrengti saugumo sumetimais, kad sargyba matytų visus, besiartinančius prie pilies; arba jie buvo reikalingi pasišviesti iškraunant laivus. Dar yra žinoma, kad kampiniame bokšte nuolat degdavęs žiburys, buvęs švyturiu atplaukiančioms Nerimi vytinèms (Klimka 2000). Europos miestai, nusileidus saulei, taip pat paskęsdavo tamsoje. $1662 \mathrm{~m}$. apsukrus prancūzų abatas Lodati gavo iš karaliaus privilegiją pašviesti kelią keleiviams. Kas 300 žingsnių Paryžiaus gatvèse buvo paskirtos vietos žibintininkams, kurie už atlyginimą palydèdavo žmones iki namų. Ši iniciatyva paskatino valdžią ịrengti nuolatinị gatvių apšvietimą.
1667 m. Paryžiuje kiekvienos gatvès viduryje ir gale buvo iškabinta po vieną žibintą. Toks apšvietimas sukèlè didelị svetimšalių nusistebėjimą, nes kitur nieko panašaus nebuvo. Prancūzijos karalius Liudvikas XIV labai didžiavosi šia naujove ir įsake nukalti ta proga specialų medali (Ishii 2007). 1669 m. Paryžiumi pasekè Amsterdamas, $1701 \mathrm{~m}$. - Leipcigas. $1824 \mathrm{~m}$. Vilniuje pasirode vadinamieji Varšuvos žibintai, kuriuose degè kanapių aliejus ir terpentinas. Miestų apšvietimas vystèsi lètai, nes šviesos šaltinių efektyvumas buvo žemas - šviesos silpnos, eksploatacija brangi, tačiau poreikis tapo akivaizdus ir buvo ieškoma kitų energijos šaltinių pritaikymo galimybių, tarp kurių jau buvo žinomos dujos ir elektra.

Dujų egzistavimas buvo žinomas nuo XVII a. ir po daugybès bandymų $1789 \mathrm{~m}$. Paryžiuje įrengtas dujinis gatvių apšvietimas. $1807 \mathrm{~m}$. dujomis pradètas apšviesti Londonas, 1826 m. - Berlynas, 1864 m. Vilnius. Miestų gatvèse dujinius žibintus iškabindavo ant 3-3,5 m aukščio stulpų arba pritvirtindavo juos prie pastatų. Kiekvieną žibintą reikejjo centralizuotai aprūpinti dujomis, vakare uždegti ir ryte - užgesinti, pastatyti dujų gamyklas ir saugyklas. Viso to nebūtų pavykę įvykdyti be projekto, o vienas svarbiausių projekto uždavinių buvo atrinkti miesto vietas, kurias reikia apšviesti. Todèl dujinio apšvietimo atsiradimas žymi ribą tarp savaiminio utilitaraus pasišvietimo ir kompleksinio suplanuoto miesto apšvietimo, kartu tai yra miesto meninio apšvietimo užuomazgų pradžia. Pirmą Vilniaus apšvietimo planą parengè prancūzas pirklys Žanas Lalansas. $1863 \mathrm{~m}$. svarbiausiose gatvèse buvo nutiesti dujotiekio vamzdžiai ir $1864 \mathrm{~m}$. spalio mèn. $22 \mathrm{~d}$. pradejjo veikti naujasis gatvių apšvietimas. Vienas to meto Vilniaus laikraštininkas aprašè, kaip grupès žmonių tą vakarą sekiojo žibintininkus ir garsiais šūkiais prie kiekvieno stulpo sutikdavo naujos šviesos pasirodymą.

İrengus miestuose dujini apšvietimą atsirado ir pirmieji oponentai, prieštaraujantys miesto apšvietimui. „Kelno laikraštis“ išspausdino straipsni, kuriame buvo pateikti motyvai, dèl kurių gatvių dujinị apšvietimą reikètų uždrausti, nes, anot laikraščio, toks apšvietimas pažeidžia amžiną Dievo nustatytą tvarką, pagal kurią naktį turi būti tamsu; vilioja žmones būti naktimis gatveje, o dèl to jie suserga tokiomis ligomis kaip kosulys, peršalimas bei plaučių uždegimas; palengvina girtuokliavimą naktị ir susilpnina tamsos baimę, saugojančią nuo nuodèmès, taip pat susilpnina apšviestų iškilmingų eisenų ir liaudies švenčių ịspūdị (Razauskas 2007). 
Nors dujinio gatvių apšvietimo atsiradimas buvo didelis žingsnis ị priekį, išgaunant dirbtinę šviesą, vis dar reikèjo saugotis gaisrų pavojų, todèl integruoti dirbtinį apšvietimą i pastatų architektūrą nebuvo įmanoma. XIX a. pabaigoje vis plačiau imta taikyti elektrą. Visame pasaulyje buvo ieškoma naujų apšvietimo technologijų, kurios tenkintų išaugusị miestų ir pramonès apšvietimo poreiki, ịvairūs išradejjai eksperimentavo bandydami surasti tinkamą elektros lemputes technologiją (Schivelbusch 1988). Skirtingų šalių autoriai, rašydami apie elektros lemputè išradimą, šią garbę priskiria savo šalies atstovams. Yra žinomas ne vienas patentas ir teisminis procesas dèl elektrinio apšvietimo autorystès, tačiau straipsnio tikslas nèra išsiaiškinti, kas pirmasis išrado lemputę, ar gilintis į technologinius elektrinių lempučių niuansus, o atskleisti, kokią ịtaką tai padarẻ meniniam miesto apšvietimui. $1879 \mathrm{~m}$. T. Edison industrializavo kaitrinių elektros lempučiu gamybos metodus ir pademonstravo apšvietimo galimybes Pasaulio technikos pasiekimų parodoje $1880 \mathrm{~m}$. Čikagoje. Tapo akivaizdu, kokią didelę ne tik funkcinę, bet ir estetinę itaką gali turèti elektrinè šviesa architektūrai (Neumann 2007).

Lietuvoje didikų Oginskių dẻka pirmą kartą elektros lempute sužibo $1892 \mathrm{~m}$. balandžio $17 \mathrm{~d}$. - per šv. Velykas įsižiebė didžiulis Rietavo bažnyčios sietynas. Kaimo žmonems tai buvo netikèta ir nauja - buvo tokių, kurie bandè prieiti prie elektros šviesos šaltinių arčiau, paliesti, pasišildyti, prisidegti pypkę, kai kuriems kaimiečiams elektra atrodè šètono sumanymu ir jie stengèsi pakenkti žmonėms, kurie tiesẻ laidus (Vyšteinaitè 2003).

Elektros panaudojimą Vilniaus gatvèms apšviesti paskatino besibaigianti $1863 \mathrm{~m}$. sutartis su Lalanso dujinio apšvietimo kompanija. $1897 \mathrm{~m}$. gruodžio $5 \mathrm{~d}$. Vilniaus miesto Dūma sudarè komisiją, kuri turèjo parengti technini projektą ir sąmatą elektriniam apšvietimui ịrengti. Nutarta, kad elektrinis apšvietimas labiau atitinka nauju laiku techninius ir higienos reikalavimus, elektrifikavimas paspartins miesto pramonès augimą. Priimtas sprendimas pastatyti centrinę elektrinę miesto léšomis. Pradžioje buvo numatyta elektrinę statyti šalia Bernardinų sodo (Sereikiškių parkas), tačiau vèliau jos statybos vieta buvo perkelta ị dešinijji Neries krantą. Buvo paskelbtas konkursas, kuriame dalyvavo daug užsienio įmonių. 1901 m. rugpjūčio mèn. prasidèjo elektrinès statyba, kuriai vadovavo Vilniaus miesto inžinierius Vladas Malinauskas. Gatvių apšvietimui įrengti buvo pasitelktas rangovas - firma Shukert and Co. $1903 \mathrm{~m}$. elektrinès statyba baigta ir ant administracinio pastato bokštelio pastatyta skulp- toriaus A. Balzukevičiaus skulptūra „Elektra“- moteris su laurų vainiku ant galvos, dešinèje rankoje laikanti žibintą su elektros lempute, o iškelta kairioji skelbia naujos šviesos eros pradžią. Prie jos kojų parkritęs elektros šviesos apakintas vyras - kairiąja ranka prisidengęs akis, o dešiniąja numeta gęstantį fakelą. $1957 \mathrm{~m}$. ji buvo nugriauta ir $1994 \mathrm{~m}$. vèl atstatyta (autorius skulptorius Petras Mazūras).

Elektros šviesa buvo ypač didelis žingsnis ị priekį, ji jau XX a. pradžioje pakankamai išplito. Tada imta masiškai kaitrinèmis lemputemis keisti dujinį apšvietimą. Dažnai buvo pritaikomi tie patys šviestuvai, vamzdeliais, skirtais dujoms, išvedžiojami elektros laidai. Elektros šviesos taikymas tapo daug paprastesnis bei pigesnis ir R. Banham įžvelgè tam tikrų pavojų: igūdžiu ir takto stoka, ịrengiant lemputes, gali paveikti ekonomiką daug labiau negu visi materialūs praejusiu metu pagerinimai. Fundamentali taisykle projektuoti šviesos šaltinị tik ten, kur naudingiausia, ir šviesą koncentruoti tik ten, kur tai labiausiai būtina, yra dažnai užmirštama ar net nežinoma (Banham 1984).

Vykstant sparčiai technikos pažangai buvo keliami nauji uždaviniai elektriniam apšvietimui, siekta sumažinti apšvietimo sąnaudas ir gerinti jo padarinius, atsirado estetiniai apšvietimo uždaviniai. Tobulèjo elektra generuojami šviesos šaltiniai.

$1902 \mathrm{~m}$. visuomenei pristatytos neoninès lempos, kurias sukūrè prancūzas Georges Claude, tačiau iki $1920 \mathrm{~m}$. neoninių lempų gamyba nebuvo pakankamai industrializuota, kad būtų plačiau naudojama. Neoninių lempų elektrinès šviesos šaltinis leido taikyti ịvairias spalvas, gaminti lempas ịvairių ilgių, todèl jos idealiai tiko prie architektūrinių detalių. Tuo pat metu vokietis Edmund Germer ištobulino baltų fluorescencinių lempų gamybą. Fluorescenicinès lempas išrado Nikola Tesla ir visuomenei pristate Pasaulinejje Kolumbo parodoje dar 1893 m. Čikagoje, tačiau tik E. Germer lempos versija buvo patogi plačiai naudoti. E. Germer pardavè savo išradimo patentą General Electric ir fluorescencinès lempos tapo plačiai naudojamu šviesos šaltiniu iki šių dienų. Fluorescencinių lempų skleidžiama šviesa, kitaip dar vadinama dienos šviesa, leido architektams nepaisyti natūralaus patalpų apšvietimo ir projektuoti gilesnes patalpas, nes nebereikejjo užtikrinti, kad saulès spinduliai prasiskverbtų giliai i pastato vidų, dèl to pastatai tapo masyvesni. Fluorescencinès lempos nenaudojo tiek daug energijos ir neskleidè tiek šilumos, todèl tapo galima projektuoti žemesnes patalpas ir numatyti daugiau aukštų. Iš fluorescencinių lempų buvo sukurtos šviečiančios lubos, labai svarbios stiklinių pastatų apšvietimui, nes kai 
šviečia lubos, iš lauko atrodo, kad šviečia visas pastatas. Tai buvo geriausias apšvietimo būdas stiklinio pastato naktiniam įvaizdžiui suformuoti.

\section{Dirbtinio apšvietimo ir menų sąveika}

Dirbtinio apšvietimo techninè raida rodo, kad apšvietimas palaipsniui igavo ne tik utilitarią, bet ir meninę funkciją. XX a. pradžioje socialinès transformacijos, politiniai neramumai, nepaprasti technologiniai ir moksliniai atradimai bei optimizmo banga kèlè didelị permainų norą, kuris atsispindèjo architektūroje ir vaizduojamajame mene. Dirbtinis apšvietimas tapo pažangos ir inovacijų simboliu, kurị pirmiausiai pasitelkè futurizmo atstovai.

Futurizmo pradžia priskiriama 1909 m., kai prancūzų dienraštis Le Figaro publikavo poeto Filippo Tommaso Marinetti manifestą del futurismo, o $1914 \mathrm{~m}$. Antonio Sant'Elia ir Mario Chiattone surenge futuristinès architektūros parodą „Naujas miestas“ Milane (1 pav.).

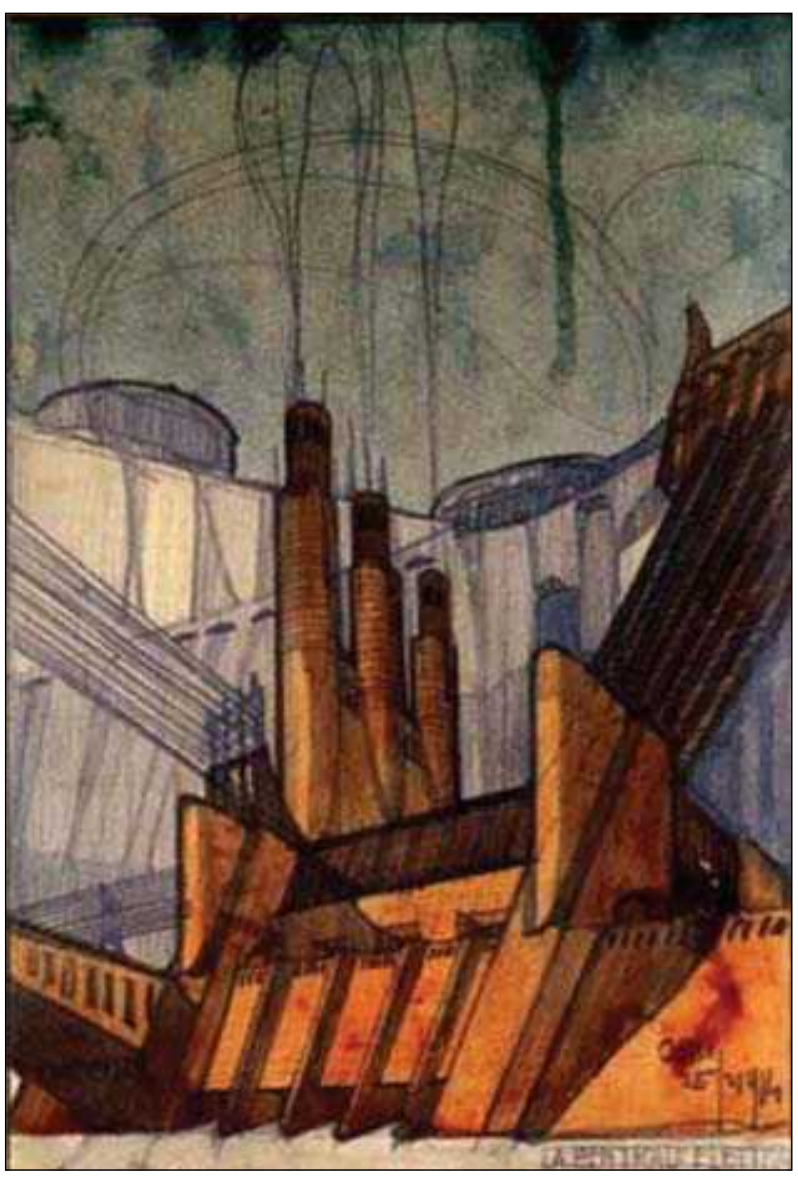

1 pav. Centrinè elektrinè (archit. Antonio Sant'Elia), $1914 \mathrm{~m}$.

Fig. 1. Central Eletric Power Station (arch. Antonio Sant'Elia), 1914
Italų futuristų kūryboje elektrinè šviesa yra progreso simbolis, kuris net verčia išblankti mènesieną. Pasaulis keičia savo rūbą, žmoniu veidai apšviečiami raudonomis, mélynomis, geltonomis spalvomis, naktinis gyvenimas gimsta (Marinetti 1909).

Moksle ir vaizduojamajame mene vyko aktyvūs dirbtinès šviesos tyrimai: šviesa yra gryniausia energijos forma ir ekstremali greičio riba. Dirbtinès šviesos greičio klausimas, jos sklaida ir judejjimas sudaro futuristinio miesto vaizdą. Futuristų tapyboje naudojamos pirminès grynosios spalvos, sukomponuotos pagal vadinamąją completamento congenito (liet. igimtas baigimas) taisyklę, pasirinkta technika yra puntualizmas. Judejjimas ir šviesa sunaikina kūnų materialumą, panaikina tradicinès perspektyvos sąvoką ir priima greičio estetiką. Giacomo Balla, vienas iš pasirašiusiųjų Manifestą, kartu su Umberto Boccioni, Carlo Carrà, Luigi Russolo, Gino Severini ypač sužavèti dirbtinès šviesos, kuri tampa viena iš fundamentalių vaizdingų ir abstrakčių paveikslų temų. Menininkai studijuoja šviesą ir J. Balla nutapo seriją abstrakčių paveikslų, kuriuose dirbtinès šviesos kovos prieš tamsą tema yra labai svarbi, pavyzdžiui, Lampada ad arco (2 pav.) paveiksle (1909 m.), kuriame vaizduojamas gatvès žibintas ne kaip paprastas miesto infrastruktūros elementas, o švytintis ir spinduliuojantis, lyg išreiškiantis veiksmą ir judejimą. Šviesa vaizduojama grynomis spalvomis, prasideda nuo labai ryškaus centro, kad skleistųsi aplink (Lighting academy 2009).

Naujos architektūros kokybė ir pažanga buvo asocijuojamos su šviesa ir skaidrumu. Siekiant integruoti apšvietimą í architektūrą, buvo ieškoma atitinkamų medžiagų. Stiklas buvo ta medžiaga, kurios platesnis naudojimas galèjo pakeisti architektūros įvaizdị. Prie stiklo ir šviesos propagavimo labai prisidejo Paul Scheerbart (1863-1915) - vokiečių poetas ir dailininkas, kuris studijavo filosofiją bei meno istoriją ir kaip daugelis XX a. pradžios aktyvių piliečių doméjosi mokslu bei technika. P. Scheerbart apsakymuose yra aprašytos ateities architektūros vizijos ir idèjos. Jis parašè daugybę grožinès literatūros kūrinių apie naujus ir radikalius pokyčius, pakeisiančius architektūrą. Apsakyme The gray Cloth yra pasakojama apie orlaiviu po pasauli keliaujantị architektą, kuris atvykęs ị svetimą šalị projektuoja šviesius ir skaidrius pastatus iš spalvoto stiklo (Stewart 2001). 1913 m. P. Scheerbart, susižavejjęs stiklo savybėmis, rašè savo žymiausią kūrinị Glasarchitektur (liet. „Stiklo architektūra"). Glasarchitektur - tai minimalistinių esè rinkinys, susidedantis iš 111 trumpų apsakymų, kuriuos vienija stiklo ir šviesos panaudo- 


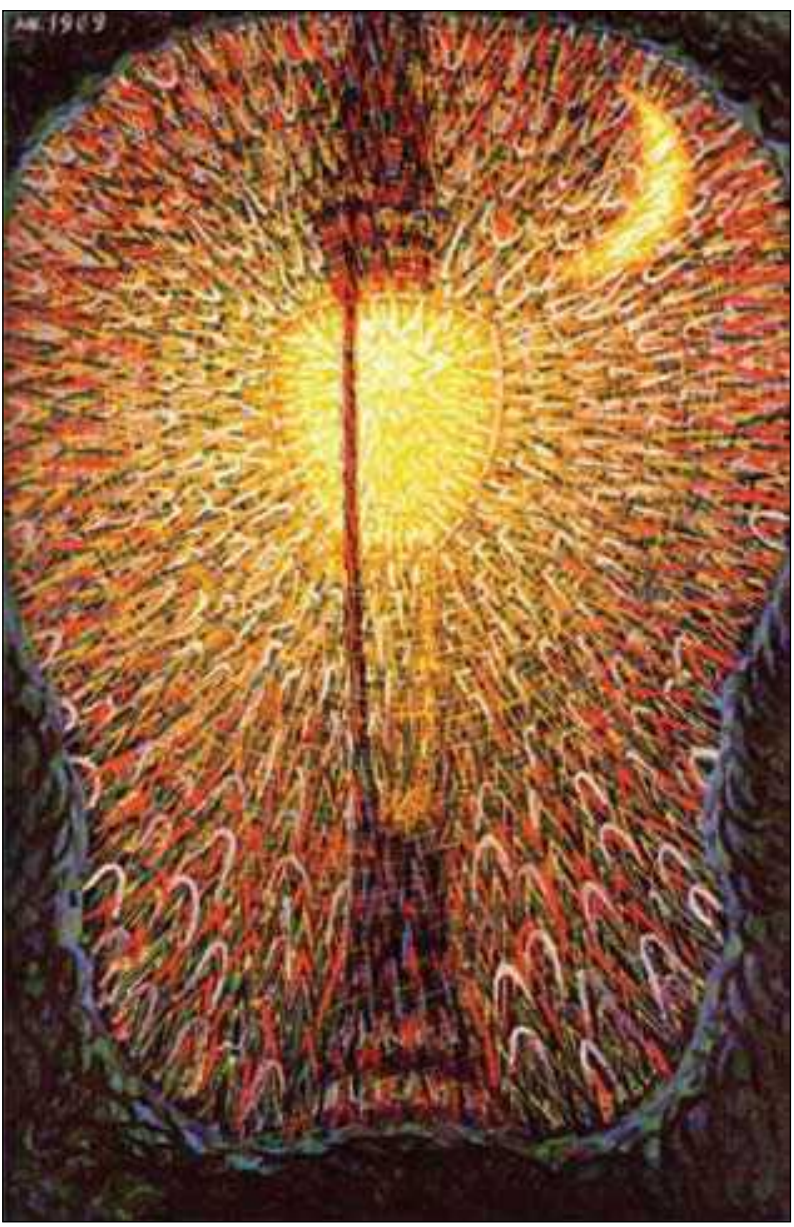

2 pav. Lampada ad arco (Giacomo Balla), $1909 \mathrm{~m}$.

Fig. 2. Lampada ad arco (arch. Giacomo Balla), 1909

jimo idèjos, atspindinčios visą P. Scheerbart pasaulèvaizdi, ideologiją ir technini susidomèjimą spalvotu stiklu bei jo galimybe skaidyti šviesą. P. Scheerbart raše: Didžiaja gyvenimo dalį mes praleidžiame uždarose erdvese. Uždaru erdviu architektūra formuoja aplinką, kurioje vystosi mūsų kultūra. Norèdami pakelti kultūros lygi turime pakeisti aplinkos architektūrą. Ir tai padaryti galima tik atsisakant uždarų erdviu - naudojant kuo daugiau stiklo. Stiklas leistu patekti saulès, mènulio ir žvaigždžiu šviesai ne tik per keleta langu, bet tuo pačiu metu per sienas, padarytas iš spalvoto stiklo. Tokioje naujoje aplinkoje turètu vystytis nauja kultūra (Conrads 1975). Tokia buvo ateities architektūros vizija, siejama su stiklo naudojimu, stiklas laikomas idealia statybine medžiaga, nes jo savybès (atspindys, skaidrumas, spalvos) leidžia integruoti dirbtinę ir natūralią šviesą ì pastatų architektūrą ịprastais ir naujais būdais. Taip pat išryškinamos dirbtinès šviesos galimybès, kurios papildo architektūrą. P. Scheerbart rašè: Kai turèsime daug šviesos, kuri bus gaunama eksploatuojant vejo ir vandens energija, nebeužteks vien tik skaidrios bespalves šviesos, o reikès spalvu, todèl mūsu tikslas nèra šviesos intensyvumo didinimas, dirbtine šviesa jau ir taip per daug stipri, o stiprios šviesos mūsu akys netoleruoja. Nuosaiki šviesa yra tai, ko mums reikia. Ne ryškesne, bet spalvota šviesa turi būti vystoma (Scheerbart 1914). P. Scheerbart siūlo įvairių architektūrinių sprendimų, vienas iš jų yra dviejų stiklų sienos. Du stiklai užtikrina termoizoliacines statinio savybes, o tarp stiklų patekusi šviesa netradiciškai nušviečia erdves, dar kitoks apšvietimas gaunamas šviesai sklindant per spalvotus stiklus. Tarp sienos dvigubų stiklų galima įmontuoti šviestuvus ir švytinčios sienos tampa naudingos interjero apšvietimui, jos yra vizualiai žymiai lengvesnès nei mūrinès, todèl architektūra atrodo neparastai šviesi ir lengva.

P. Scheerbart stiklo architektūros vizijas išplètè iki viso miesto mastelio. Pastatai su šviečiančiomis stiklo sienomis yra svarbūs ne tiek savo interjero savybėmis, kiek viso miesto mastu, jie yra savarankiški miesto šviesos šaltiniai stiklinis pastatas tampa dideliu žibintu ir nakti šsvyti kaip jonvabalis (Schererbart 1914). P. Scheerbart išskyrè dominantes ir rašè, kad miestai turi išsiskirti bokštais ir kiekvienas miesto pastatas turi būti suprojektuotas taip, kad paskolintų savo žavesị tiems bokštams naktị. Tamsiuoju paros metu visi miesto bokštai turi tapti šviesos bokštais (Scheerbart 1914).

P. Scheerbart kūryba ir jo idejjos įkvèpé daugybę pasekejų, kurių pirmasis buvo jaunas architektas Bruno Taut, suprojektavęs Stiklo paviljoną (3 pav.) ir šiame projekte igyvendinęs P. Scheerbart vizijas. Tai buvo laikinas Werkbund parodai skirtas pastatas, finansuotas vokiečių stiklo gamintojų ir sunaikintas iškart uždarius parodą. Išlikusios tik nespalvotos pastato fotografijos. Paviljonas buvo nedidelis su apvaliu briaunuotu kupolu ir stiklo blokelių sienomis. Ant paviljono fasadų buvo užrašyti P. Scheerbart poleminiai aforizmai: Šviesa nori kristalo, Be stikliniu rūmu gyvenimas tampa našta ir Statantis iš plytu tiktai padaro žala. Visas interjeras žèrèjo ịvairiomis spalvotomis šviesomis, patekusiomis pro stiklines sienas ir spalvotų stiklų kupolą, šviesą reflektavo baseinas ir spalvotos mozaikos. Grindys ir laiptai taip pat buvo stikliniai, po grindimis buvo spalvotų stiklų kaleidoskopas (Thiekotter 2007). Stiklo paviljonas svarbus architektūros ir miestų meninio apšvietimo raidai, nes tai buvo pirmas vien tik stiklo pastatas, skirtas tik grožiui, jame buvo atskleistos dirbtinès ir natūralios šviesos estetinès galimybès. 


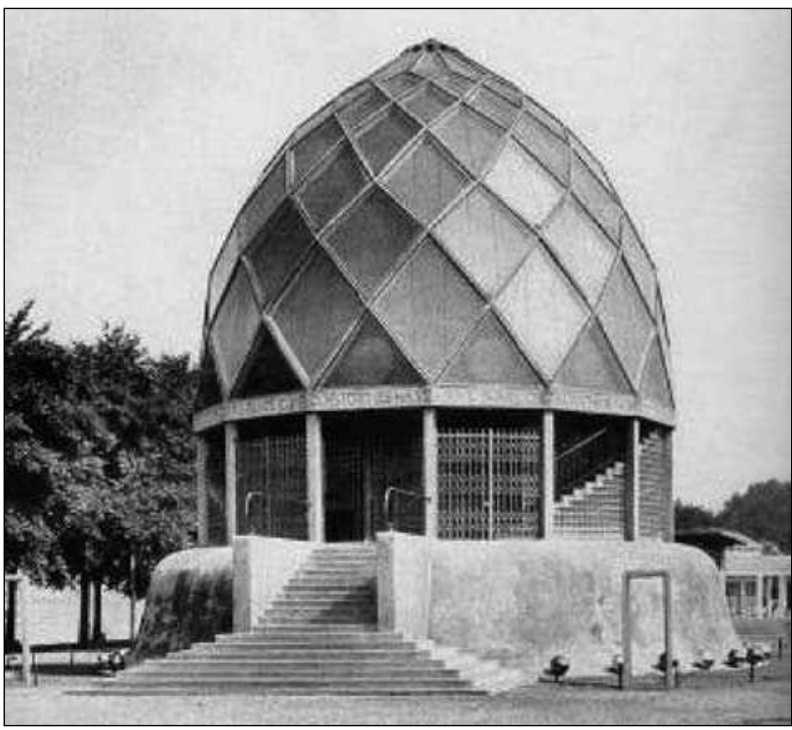

3 pav. Stiklo paviljonas (archit. Bruno Taut), Kelnas, 1914 m. Fig. 3. Glass Pavilion (arch. Bruno Taut) Cologne, 1914

B. Taut ir P. Scheerbart draugystę liudija tai, kad P. Scheerbart savo žymųji kūrinị Glas architektur dedikavo B. Taut, o B. Taut stiklini paviljoną paskyrè P. Scheerbart. P. Scheerbart kūrybą galima vertinti kaip vieną iš tų didžiųjų minties srovių, kurios padejo suformuoti dvidešimto amžiaus architektūrą ir menini miesto apšvietimą. P. Scheerbart drąsios naujo pasaulio vizijos, kuriose visi pastatai sukonstruoti iš švytinčio, spalvoto stiklo, padarè įtaką Vokietijos architektams, B. Taut iniciatyva susibūrusiems ị grupę Die Glaserne Kette (liet. „Stiklo grandine““). Šios grupès nariai įsipareigojo savarankiškai mąstyti ir keistis idèjomis apie architektūros ateitį. Žymiausi grupès nariai buvo Hans Scharoun, Hermann Finsterlin ir Walter Gropius, kurie suformavo vokiečių ekspresionizmo pamatus.

B. Taut toliau vystè P. Scheerbart vizijas po I pasaulinio karo. B. Taut leido žurnalą Frülicht (liet. „Ankstyva šviesa"), kuriame publikavo dalị „Stiklo grandinès“ narių susirašinèjimų $1921 \mathrm{~m}$.

Meninio apšvietimo galimybèmis labai domejosi Bauhaus mokyklos menininkai ir pedagogai Lazlo Moholy-Nagy bei Gyorgy Kepes. Ju atlikti eksperimentiniai darbai apšvietimo srityje, savitas modernumo doktrinų formulavimas, apšviestos aplinkos supratimas ir kūrimas atkreipé daugelio menininkų dėmesị $i$ meninio apšvietimo galimybes. Ryškiausias MoholyNagy darbas, susijęs su šviesos eksperimentais, yra šviesos ir erdvės moduliatorius, tai yra kinetinè meno skulptūra, kuri sudaryta iš įvairių paviršiu šviesos velenų, besikeičiančių nuo krentančios šviesos projekci- jos ir užpildančių erdvę įvairiais šviesos atšvaitais bei metamais persidengiančiais šešèliais (4 pav.).

L. Moholy-Nagy ir G. Kepes sukūrè filmą apie šviesos ir erdvès dipolio eksperimentus „Šviesos žaismas: juoda, balta, pilka" (Lightplay: black, white, grey) $1930 \mathrm{~m}$. Filme rodomas moduliatoriaus veikimas ir metami šešèliai sujungti su Moholy įrašais apie miestų aplinką kaip pulsuojančią šviesos skulptūrą. Šviesos modelis gana abstraktus ir primena mirgančias šviesas naktiniame miestovaizdyje nuo reklamų, automobilių šviesų, gatvių apšvietimo iki atskirų pastatų šviesų. Modelis puikiai iliustruoja dinamišką miesto apšvietimą. Abstraktaus vaizduojamojo meno technika sukuriama atitinkama besikeičianti naktinio miesto nuotaika ir atmosfera.

Bauhaus filosofijoje abstrakcija pasireiškia kaip intelektinè siekiamybè, kuri pastebima daugumos Bauhaus mokyklos menininkų darbuose. L. MoholyNagy savo darbuose naudojo įvairias persidengiančias plokštumas, kurios sudarydavo apšvietimo ir trijų dimensijų erdvès ịspūdị plokštuminèse kompozicijose (5 pav.). L. Moholy-Nagy darbai yra geriau supranta$\mathrm{mi}$, žinant, kokie tuo metu buvo pagrindiniai šviesos šaltiniai, kaip jie apšviesdavo erdvę - dažniausiai tai buvo stiprios šviesos lankinès lempos, sukuriančios ryškius formos paviršių kontrastus visiškai netikètomis kryptimis.

Technologinès naujovès skatino plačiai naudoti fotografiją ir kiną. Laszlo Moholoy-Nagy ir Naum Gabo bandè atrasti šviesos variklị ir kūrè šventinius apšvietimus festivaliams. Teatras ir kino filmų pasaulis taip pat žavejjosi meninėmis šviesos galimybėmis.

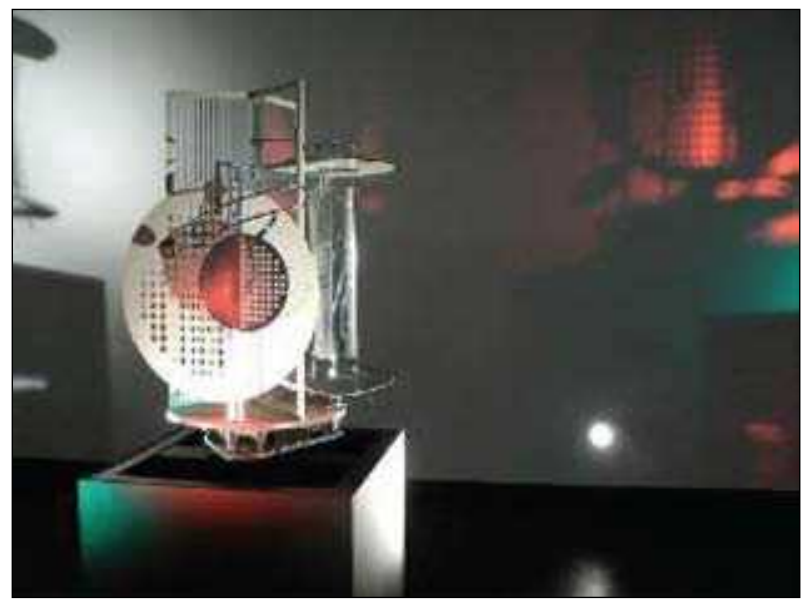

4 pav. Šviesos ir erdvès moduliatorius (archit. Lazlo Moholy-Nagy), $1930 \mathrm{~m}$.

Fig. 4. Light-Space Modulator (arch. Lazlo Moholy-Nagy) , 1930 


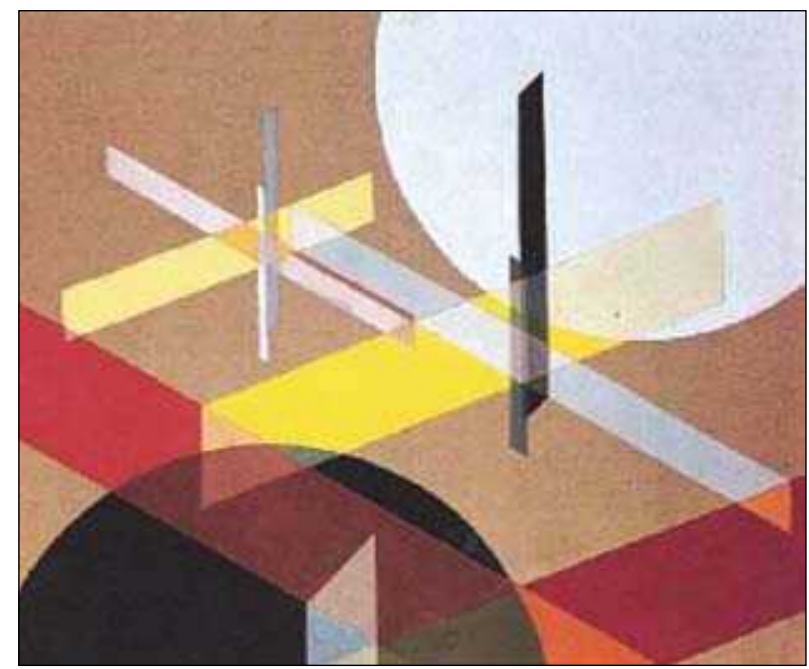

5 pav. Kompozicija Z VIII (Lázló Moholy-Nagy), 1924 m.

Fig. 5. Composition Z VIII (arch. Lázló Moholy-Nagy), 1924

Oscar Schlemmer darbe Light plays buvo vaizduojama meniškai apšviesta architektūra. Fritz Lang 1927 m. epinè poema „Metropolis“ (6 pav.) ir Alexander Korda Things to come rodo nuolatinị mąstymą apie šviesos architektūrą. Virpanti apšviesta aplinka, šviečiantys komercinių pastatų fasadai keitė menininkų erdvès suvokimą, atsirado autorių, kurių darbuose èmè dominuoti dirbtinès didelių kontrastų ir aštrių kontūrų šviesos. Tapytojas Degas net teigè, kad dirbtinè šviesa jam priimtinesné, nes stiprūs saulès spinduliai, anot menininko, gadina jam akis (Ishii 2007).

\section{Dirbtinis apšvietimas architektūroje}

Walter Gropius buvo „Stiklo grandinès" narys, ilgą laiką vadovavo Bauhaus menų mokyklai ir stengèsi plètoti P. Scheerbart vizijas. Jis rašè menininkui Herman Finsterlin: Jūs būtinai turite perskaityti Paul Scheerbart $\langle\ldots . .>$, jo darbuose jūs surasite daug išminties ir grožio (Stewart 2001). B. Taut, W. Gropius, Hermann Muthesius ir Mies Van Der Rohe siejo idejjos apie šviesą ir stiklą, kurias iliustruoja M. Van Der Rohe konkursinis projektas novatoriškam stikliniam dangoraižiui Friedrichstrasse, Berlyne 1921 m. M. Van Der Rohe apie savo konkursinį darbą rašè: Mes galime aiškiausiai pamatyti naujus struktūrinius principus, kai panaudojome stikla vietoje išoriniu sienu $\langle\ldots\rangle$, stiklo naudojimas skatina naujus sprendimus $\langle\ldots\rangle$, aš dirbdamas su stiklu atradau, kad labai svarbus dalykas yra šviesos atspindžiu žaismas stikliniuose modeliuose, o ne forma ir šešèliai kaip ipprastuose pastatuose (Banham 1961).
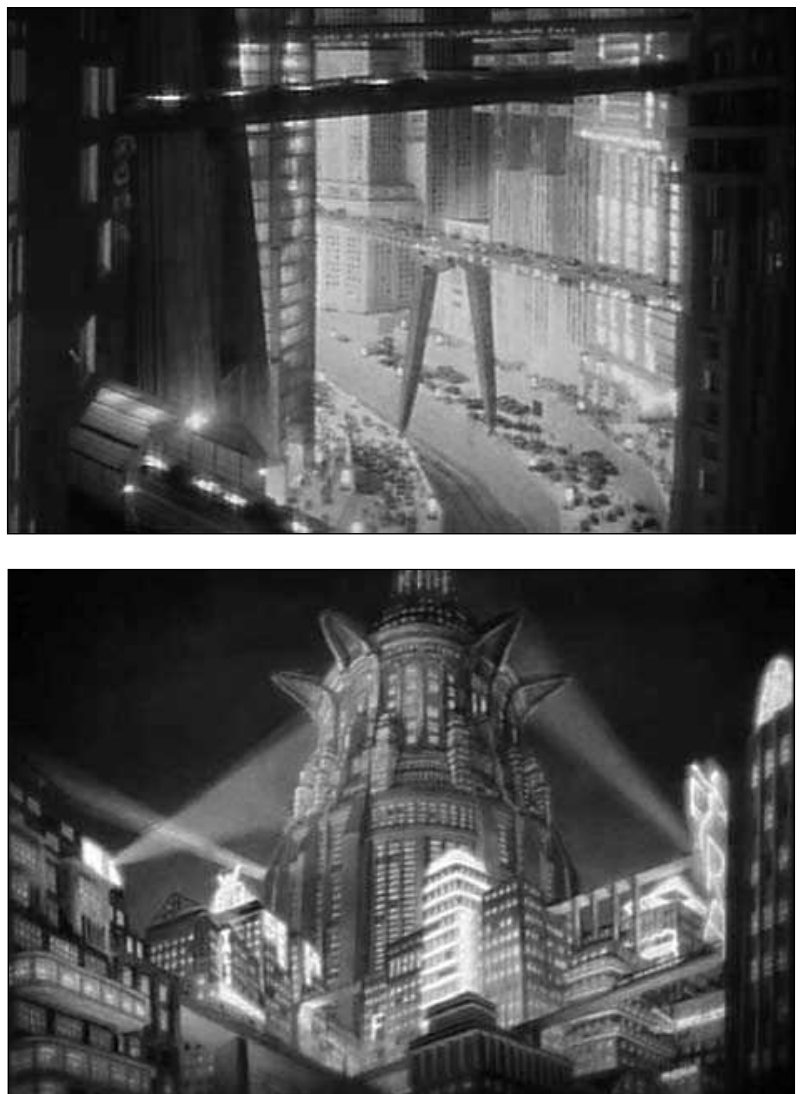

6 pav. Kadrai iš kino filmo "Metropolis", $1927 \mathrm{~m}$.

Fig. 6. Frames from film "Metropolis", 1921

Didelę įtaką miesto meninio apšvietimo ir modernizmo architektūros sąveikai padaré žydų kilmès architektas Erich Mendelsohn, dirbęs Berlyne nuo $1918 \mathrm{~m}$. ir per savo karjerą suprojektavęs daug modernistinių pastatų, tokių kaip Einstein Tower Potsdame 1917 m., prekybos centras Shocken Štutgarte 1926 m. (7 pav.), Herpich Berlyne 1920 m. ir Rudolf Petersdorff Department store Vroclave $1928 \mathrm{~m}$. Anot E. Mendelsohn, pirmasis sąmoningas šviesos ženklo inkliuzas architektūroje yra pasléptas apšvietimas pastato languose. Taip jis pristate modernų savo projektą Shocken Štutgarte. Čia E. Mendelsohn architektūra buvo labai novatoriška, nes elektrine šviesa buvo integruota i pastato formas per dideles vitrinas ir langu juostas, tolygiai apšviestas sienas ar šviečiančias stiklines lubas. E. Mendelsohn fasaduose naudojo žaliuzes, kurios skaidè šviesą ir suformuodavo įvairius šešèlius, taip pat fasadai išsiskyrẻ didelèmis šviečiančiomis raidèmis, kurios buvo neatsiejama architektūros dalis. E. Mendelsohn mokejjo dirbtinį apšvietimą suprojektuoti taip, kad nesimatytų tiesioginių šviesos šaltinių, o pati šviesa sudarydavo ịspūdị, kad sklinda savaime, ne- 


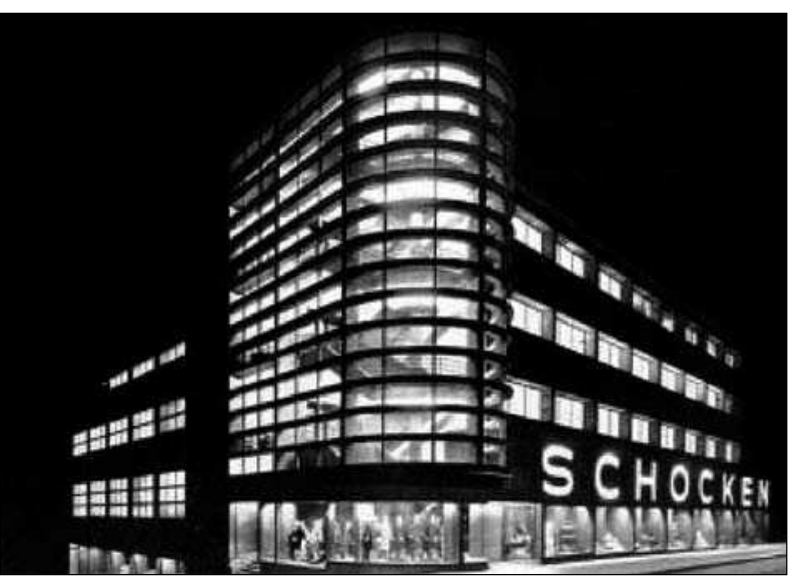

7 pav. Shocken prekybos centras (archit. E. Mendelsohn), Štutgartas, 1926 m.

Fig. 7. "Shocken" shopping centre (arch. E. Mendelsohn), Stuttgart, 1926

priklausomai nuo architektūros. E. Mendelsohn daug dèmesio skyrè dirbtiniam apšvietimui ir savo kūrybą laikè šviesos architektūra.

1925 m. E. Mendelsohn iniciatyva susiformavo grupé, pasivadinusi Der Ring (liet. „Žiedas“), kuriai priklausė W. Gropius, L. M. Van Der Rohe ir kiti ankstesnès „Stiklo grandinès“ nariai. Grupès nariai daug dèmesio skyrè pastatų naktinio fasado įvaizdžiui, todèl jų kūryba padarè didelę įtaką miesto meninio apšvietimo raidai. Architektūros apšvietimo reikšmingumas stiprèjo visoje Europoje, daugejo apšvietimų metodu ir plètėsi apšviečiamų pastatų tipologija: apšviečiami buvo ne tik administracinès ar komercinès paskirties, bet ir gyvenamosios paskirties namai.

Pierre Chareau ir Bernard Bijvoet $1931 \mathrm{~m}$. suprojektavo privatų gyvenamąji namą Maison Verre Paryžiuje, kuris tapo modernios architektūros pavyzdžiu, išsiskiriančiu šviečiančiu stiklo blokelių fasadu. Blokeliai sumontuoti plieniniuose rèmuose, unikali fasado sistema praleidžia dienos šviesą ir suderinta su paslèptu reguliuojamo stiprumo apšvietimu, kuris užtikrina netiesiogini šviesos foną ir jaukų apšvietimą pastato viduje (8 pav.). Meninio apšvietimo požiūriu svarbus yra visas šviečiantis pastato fasadas, kuris gali būti suvokiamas kaip didelis šviestuvas, tai yra vienas pirmųju tokių fasadų pavyzdžių.

Kitas panašus didesniame plote naudojamo dirbtinio apšvietimo pavyzdys yra Gerrit Rietveld suprojektuotas šviečiantis fasadas Bioscoop Vreeburg kino teatrui Utrechte 1936 m. (9 pav.).

Reikia paminèti ir skandinavišką architektūros tradiciją - jos atstovai architektai Gunnar Asplund, Alvar Aalto, Eliel Saarinen, kurių darbuose šviesa vi-

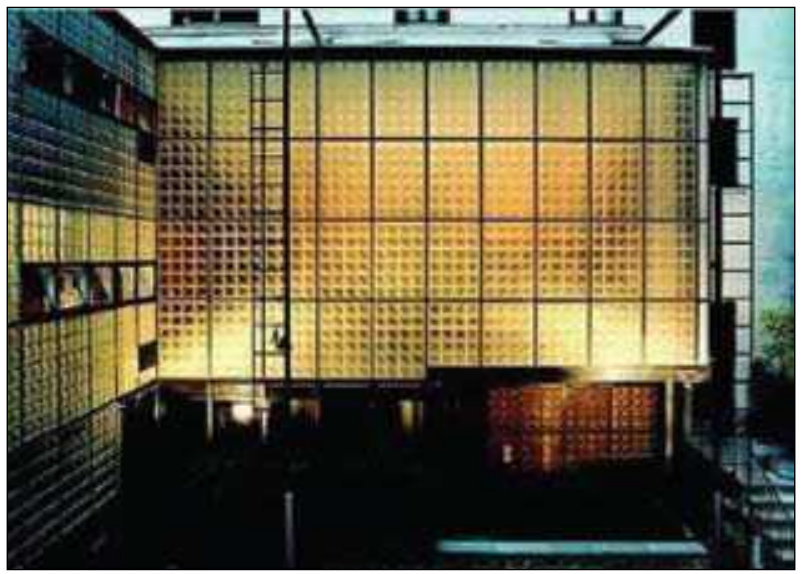

8 pav. Gyvenamasis namas Maison Verre (archit. P. Chareau ir B. Bijvoet), Paryžius, 1931 m.

Fig. 8. Dwelling house "Maison Verre" (archs. P. Chareau and B. Bijvoet), Paris, 1931

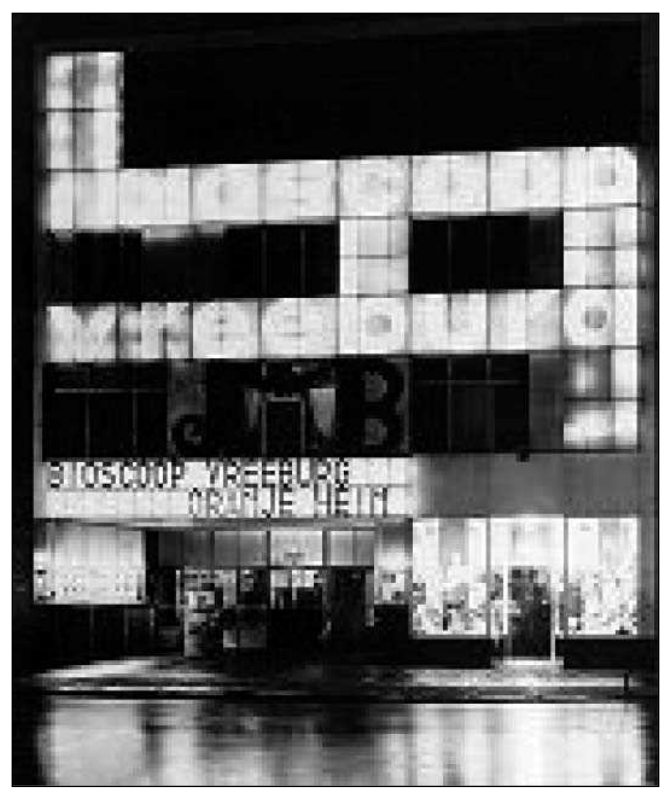

9 pav. Bioscoop Vreeburg kino teatras (archit. Gerrit Rietveld), Utrechtas, $1936 \mathrm{~m}$.

Fig. 9. "Bioscoop Vreeburg" cinema (arch. Gerrit Rietveld), Utrecht, 1936

suomet buvo integruota architektūros dalis. Alvar Aalto suprojektavo puikią detalę - stiklinius stoglangius, sujungiančius dieninị ir naktinị pastato apšvietimus Viipuri (Vyborgo) bibliotekoje $1935 \mathrm{~m}$.

Dirbtinio apšvietimo raidą nuo XX a. pradžios iki vidurio D. Neumann vadina efemeriniu meninio apšvietimo laikotarpiu todèl, kad Antrasis pasaulinis karas, vèliau 1970 m. energetinè krizè, visokių normų suvaržyta technikos pažanga lèmė, kad buvo visiškai užmiršti šimtmečio pradžios meniniai apšvietimo 
pasiekimai (Neuman 2002). Nagrinejjant ankstyvus elektrinio apšvietimo pavyzdžius JAV, svarbu suprasti, koks buvo architektų požiūris ị dirbtinį apšvietimą. Apšvietimo projektuotojai siekdavo imituoti dieną ir atkartoti pro langus ar kitas angas i pastatus krintančią natūralios kilmès saulès šviesą, o architektai neskyrè dirbtiniam apšvietimui pakankamai dèmesio, pasak R. Banham: Šios (elektrinio) apšvietimo sistemos progresas buvo tiek greitas, kad architektai nespejjo atkreipti demesi i jo menines galimybes, bet kai jie tai padarys, jie supras, kaip ịvykdyti visus puikaus apšvietimo reikalavimus (Banham 1984). Jie tai suprato po Antrojo pasaulinio karo, kai daugybè menininkų ir architektų iš Europos persikèlè ị JAV, kur tęsè savo veiklą ir lèmè meninio apšvietimo raidą.

\section{4. Šviesos architektūra ir reklama}

Hugo Hering, vokiečių architektas funkcionalistas, buvo Der Ring ir CIAM (Congrès International d'Architecture Moderne) narys, jis pirmasis atkreipe dèmesị i šviečiančias reklamas ir įžvelgè informacinę pastatų fasadų funkciją (Ward 1963). Itin didelio intensyvumo teritorijose esančių pastatų fasadus užvalde šviečiančios reklamos: New York Times Square (10 pav.), London Piccadilly Circus. Fasaduose èmé dominuoti vien tik reklamos, kurios egzistuoja iki šių dienų ir tapo šių miestų neatskiriama ịvaizdžio dalimi.

Vokietijoje daugiau nei kitose šalyse paplito šviečiančios reklamos, buvo perprojektuojami ir lyginami pastatų fasadai, kad ant jų būtų galima sumontuoti šviečiančias reklamas. Ekspresionisto architekto Hans Scharoun 1921-1922 m. sukurtame dangoraižio konkursiniame projekte reklamos buvo numatytos dar kūrybiniu pastato etapu. Pastatuose èmè dominuoti dideli reklaminiai tekstai, kurie kartais užimdavo visą ar net visus pastato aukštus. Pasak B. Taut, geriau pakeisti namo fasada, kad atitiktu reklama, negu turèti reklama, kuri netinka prie fasado, reikia, kad reklama ir fasadas kalbètu ta pačia kalba (Ward 1963). Vis daugiau architektų projektavo šviečiančias reklamines struktūras. H. Hering pažymèjo, kad miesto naktinis įvaizdis pranoko dieninị ir daugèja pastatų, kurių fasadai, be šviečiančios reklamos, daugiau jokios meninès vertès neturi (11 pav.), kad reklama okupuoja ir mažąsias architektūros formas ir buvusi telefono budelè tapo šviečiančia budele (vokiečių kalba atskiras pavadinimas telefonsaule), autobuso laukimo stotele pavirto i šviečiančią stotelę (haltsaule) (Ward 1963).

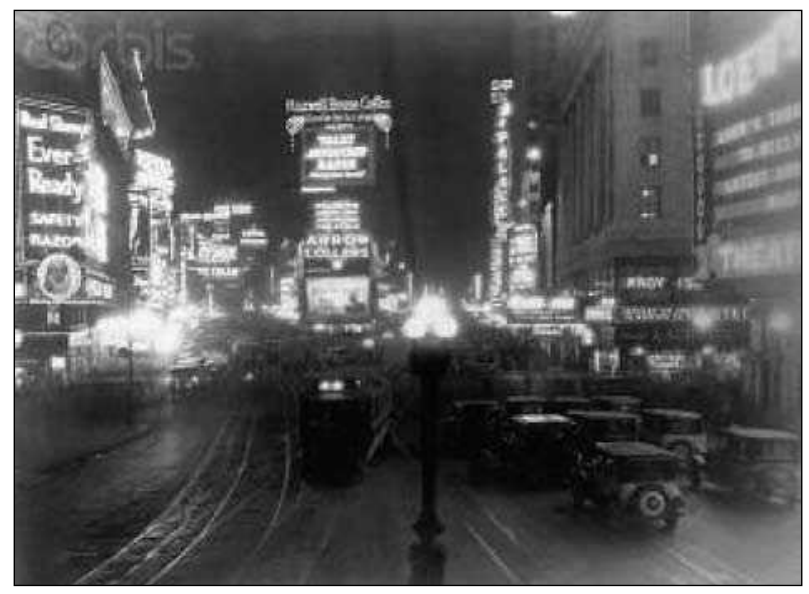

10 pav. Times aikštè, Niujorkas, $1920 \mathrm{~m}$.

Fig. 10. Times Square, New York, 1920

Vokiečių kino kritikos žurnale Reichsfilmblatt 1929 m. šviesos architektūra buvo apibrèžta kaip reklaminè statybos forma, kai šviesa yra panaudota kaip pastato elementas, formuojantis švytintị paviršiu, šviesos architektūra yra ịprastos (dieninès) architektūros negatyvas, tai paskutinis žanras ir profesija. Žurnale teigiama, kad šviečiančias reklamas reikia naudoti transformuojant gremėzdiškus ir senamadiškus pastatu fasadus ị labai šiuolaikinius fasadus, šviečiančius naktį. $\mathrm{XX}$ a. antrajame ir trečiajame dešimtmečiuose didelę ittaką miesto apšvietimui darẻ Bauhaus menų ir amatų mokykla. Daugumos Europos miestų, ypač Berlyno, gatvių apšvietimas tapo îprasta realybe (Neumann 2002).

Lietuva taip pat neatsiliko ir stengèsi, kad laikinoji sostinè Kaunas būtų modernus Europinio lygio miestas, todèl daug dèmesio skirta viso miesto ir ypač centro apšvietimui. Apie apšvietimo priemonių šiuolaikiškumą liudija to meto lenkų karo atašè atsiminimai: <...> išvažiavome ị labai plačia, puikiai išasfaltuota, gausiai apšviestą, pilna šviesos reklamu gatvę, apsodinta dviem eilèmis medžiu. Tai buvo Laisvès aleja - Nepriklausomybess alejja - naujajame Kaune (Mitkiewicz 1939). Tarpukario Lietuvos architektai projektavo namus modernizmo stiliumi. Galima rasti daug panašumų tarp E. Mendelsohn projektuotų prekybos centrų ir Centrinio pašto (1930-1931, archit. Vizbaras) ar Pieno centro rūmų (1937-1934, archit. Landsbergis-Žemkalnis). Kauno miesto apšvietimas savo menine raiška turèjo būti artimas to meto Berlyno miesto apšvietimui. Tarpukario Kauno architektūrai būdingos lenktos formos, lengvumas, kampiniai arba 


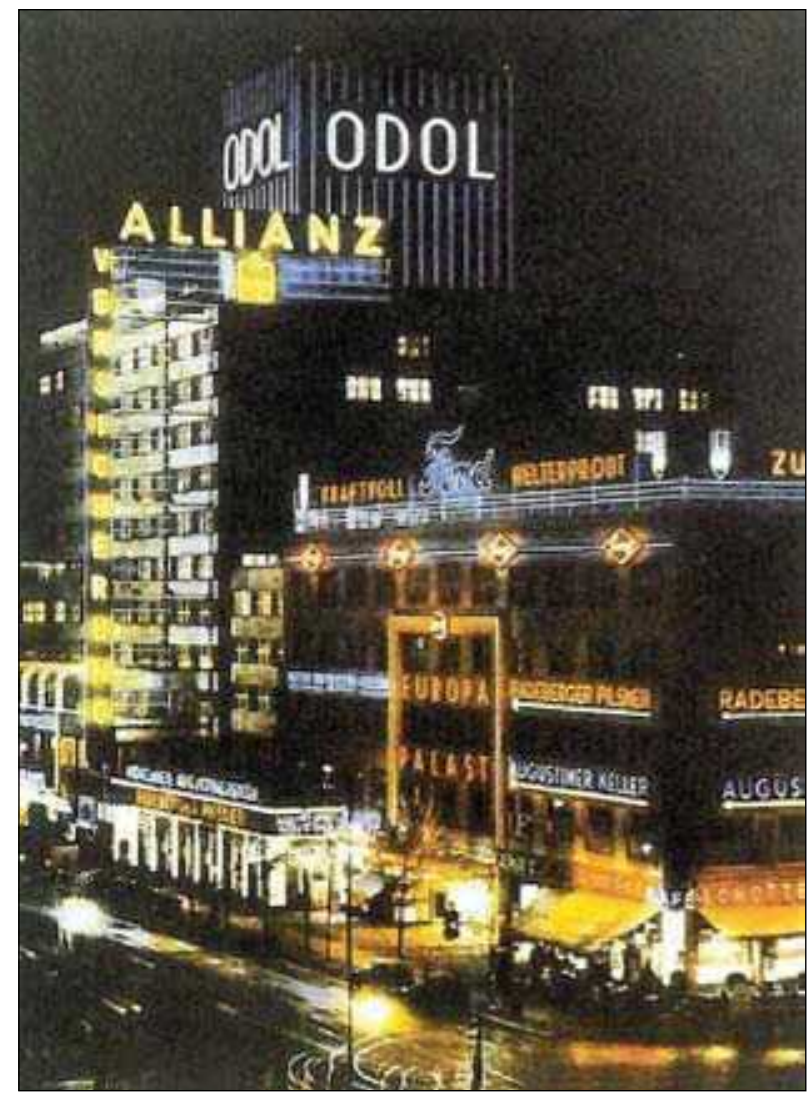

11 pav. Europos prekybos centras Berlyne, 1936 m.

Fig. 11. "Berliner Europhaus" shopping centre, 1936

lenkti langai, langų juostos suformuodavo šviečiančius fasadus. Visi šie bruožai liudija, kad tarpukario Kaunas (12 pav.) buvo šiuolaikiškas miestas (Kančienė 2000).

1927 m. Joachim Teichmuller plètojo šviesos architektūros temą straipsnyje Lichtarchittektur (liet. „Šviesos architektūra“), žurnale Licht und Lampe. Tiesioginių sąsajų tarp „Stiklo grandinès“, „Žiedas“ ir J. Teichmuller kūrybos nèra, tačiau tikètina, kad jam didelę itaką darè Bauhaus mokykla ir vokiečių ekspresionistai. J. Teichmuller rašè, kad apšvietimo technologijų nauda yra ne tik šviesos šaltinių sukūrimas, bet taip pat ir tai, kad šviesa gali būti valdoma, gali apibrèžti erdvę, tūrị ir pati turèti formą, taip ji tampa architektūrą formuojančiu elementu ir visa tai sudaro šviesos architektūrą (Major 2007). Rašydamas apie šviesos architektūrą J. Teichmuller pakartoja labai panašias idejjas, kurias jau prieš dešimtmetị buvo publikavęs $P$. Scheerbart, tačiau J. Teichmuller disponuoja platesnèmis techninèmis žiniomis, jis rašo apie elektrinio apšvietimo įtaką erdvès formavimui: Šviesos architektūros užduotis yra iliuminacija; architektūra turi savarankiškai gaminti šviesa ir naudotis ja kaip ir kitais struktūriniais elementais. Šviesa negali daugiau

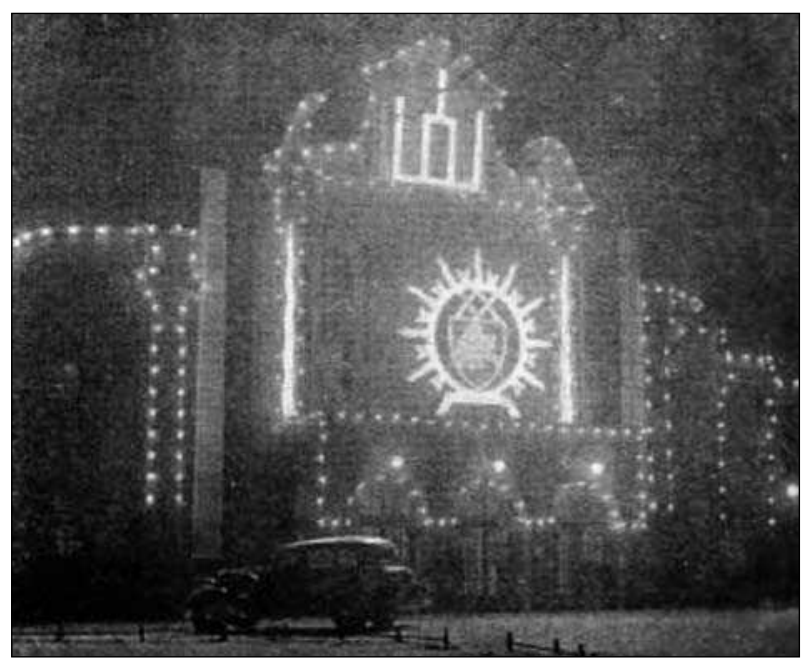

12 pav. Valstybès (dab. Kauno muzikinis) teatras. Apie $1938 \mathrm{~m}$.

Fig. 12. Kaunas State Musical Theatre, 1938

būt naudojama kaip dekoravimo priemone ir jai turi büt skiriamas lygiavertis demesys kaip ir kitiems struktūriniams elementams. Šviesa tai įrankis architekto rankose, kuriuo jis gali determinuoti erdvę (Werner 2002). J. Teichmuller papildo savo pirmtakus formuluodamas šviesos architektūros tikslą: architekto užduotis suteikti funkcija šviesai (ir šešèliui), kuri suformuotu erdvę naujais dirbtinès šviesos suteikiamais büdais. Architektas turi žinoti šviesos sukeliamus pavojus, nepamiršti, kad švytinčios juostos bei taškai gali sukurti ir akcentuoti tam tikrus elementus erdveje, taip pat ir sutrikdyti ar sunaikinti šios erdves atmosferą. Reikia žinoti, kaip teisingai naudoti dirbtinę šviesa, jausti jos intensyvuma ir spalva, moketi nuspalvinti lubas bei sienas. Šviesa gali pakeisti pastato formu medžiagiškuma. Apšvietimas reikalingas, kad būtu galima matyti - tam reikia šviesos, bet taip pat reikalingas, kad bütu sukurtas menas - meno funkcija atlieka šviesos architektūra. $<\ldots>$ Apšviesdami mes sukuriame forma, taip kurdami forma mes deriname ją su šviesa ir pasiekiam vienovę. Šiame procese mes turime išvengti seno saules mègdžiojimo, mes turime žinoti geriau negu saule (Teichmuller 1927). J. Teichmuller žodžiai parodo, kad architektūros ir meninio apšvietimo vertybès buvo pastebètos gana anksti.

Vienas iš îspūdingiausių šviesos architektūros pavyzdžių, kuris buvo sukurtas išnaudojant šviesos kaip formos kūrimo galimybes, buvo architekto Albert Speer Licht Dom (liet. „Šviesos katedra“). A. Speer panaudojo daugybę prožektorių ir sukūrè ịspūdingą šviesos reginị per baigiamąją Berlyno Olimpinių žaidynių ceremoniją 1936 m. (13 pav.). 


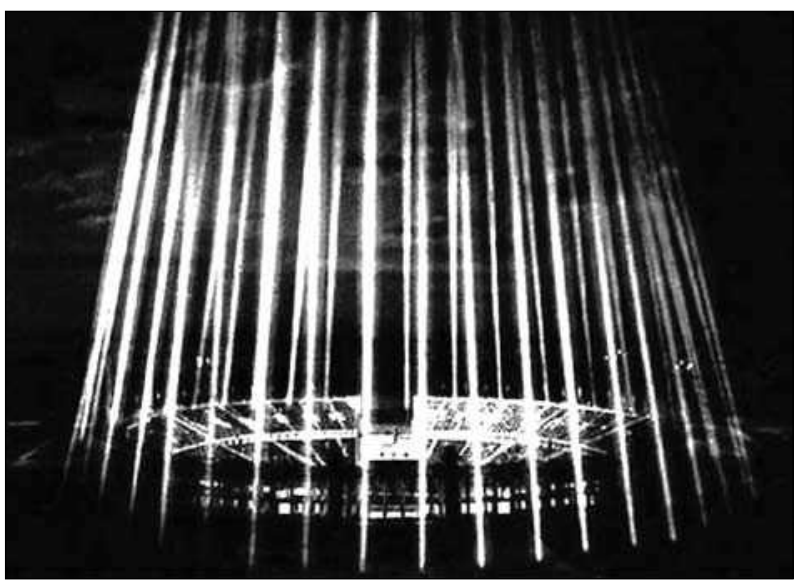

13 pav. Olimpinių žaidynių ceremonija (archit. A. Speer), 1936-1939 m.

Fig. 13. Ceremony of Olympic Games (arch. A. Speer), 1936-1939

A. Speer kūrẻ dramatiškus šviesos reginius naudodamas priešlèktuvinius prožektorius, fakelus, vèliavas ir kitą nacių simboliką. Prožektoriai buvo išrikiuoti i eilę ir jų skleidžiamas koncentruotas šviesos srautas sukūrẻ kolonų iliuziją, begalinę sieną nuo žemès ligi dangaus (Krauter 1997). Šie prožektoriai pirmą kartą panaudoti per Pirmąji pasaulinị karą naktinių priešlèktuvinių atakų metu. A. Speer suderino tuo metu vyravusio architektūrinio komponavimo principus (kolonada, simetrija, proporcijos) ir pažangias technologijas. „Šviesos katedrą" galima įsivaizduoti kaip labai įspūdingą ceremoniją ir šiandien, nors šviesos efektų kupini visi koncertai ir diskotekos, o 1937 m., kol dar nebuvo televizijos, žmonès stebejosi net paprasčiausiais radijo imtuvais, tai galima tik spèlioti, kokia sẻkmẻ lydejo šị ịvykị ir kokią įtaką tai padarè žmonių masėms. Šios sèkmès priežastis buvo naujas šviesos efektų pritaikymas.

\section{Išvados}

1. Nuo pat atsiradimo elektrinis apšvietimas buvo laikomas kaip novatoriškas ir pažangus inžinerinis techninis reiškinys.

2. Modernizmo laikotarpiu apšvietimas buvo nagrinèjamas ne tik kaip fizikos reiškinys, jo savybès ir tiesioginis poveikis žmogui buvo sprendžiami kartu su meno bei architektūros uždaviniais.

3.XX a. pirmoje pusėje sparčiai formavosi jau ir miesto apšvietimas, pagristas racionalumu bei funkcionalumu. Šis reiškinys neabejotinai turejo ịtakos architektūrai ir modernizmo estetikai apskritai.
4. Nors apšvietimo prigimtis pradžioje buvo grynai funkcionali, ji greitai igavo simbolinių ambicijų: reprezentuoti architektūrą.

5. Modernizmo architektai ị apšvietimą žvelgè ne tik kaip ị technologinę pažangą, tai buvo naują erą ženklinantis simbolis, erą, kurioje atsiranda didelès itakos visoms modernizmo idejoms turinti nauja savarankiška kūrybos sritis - šviesos architektūra.

\section{Literatūra}

Banham, R. 1984. The Architecture of the Well Tempered Environment. University of Chicago Press 1969.59 p.

Banham, R. 1961. Theory and Design in the First Machine Age. London: Architectural press. 268 p.

Banham, R. 1988. Edison. Missing Pioneer - Daidalos 27 Lichtarchitektur, in The Architecture of Light. Bertelsmann Berlin, 48.

Conrads, U. 1975. Programs and Manifestoes on 20th Century Architecture. MIT, Cambridge Massachusetts. 87 p.

Ishii Akara-Lisa. 2007. ELDA+ Ligt focus, in Conference Where is urban lighting going to, Via-verlag Guetersloh, 44-47.

Kančienè, J. 2000. Tarpukario pastatai, iš Kauno technologijos universiteto pastatai: istorija ir architektūra. Kaunas: Technologija, 95-130.

Klimka, L. 2000. Vilniaus gatvių žibintai: istorija ir dabartis, Archiforma (1): 1392-4710.

Jakle, J. 2001. City Lights: Illuminating the American Night. Baltimore: The Johns Hopkins University Press. 304 p.

Krauter, A. 1997. Die Schriften Paul Scheerbarts und der Lichtdom von Albert Speer - „Das grosse Licht“. InauguralDissertation zur Erlangung der Doktorwürde an der Philosophisch-Historischen Fakultät der Ruprecht-KarlsUniversität Heidelberg. 281 p.

Le Corbusier. 1923. Toward an Architecture. Los Angeles: Getty Research Institute.

Lighting academy Manifesto tecnico della pittura futurista [interaktyvus] [2009 04 15]. Prieiga per internetą: $<$ http://www.lightingacademy.org >.

Major, M. 2007. Learning from the past-from Scheerbart to Ito: a schort eamination of the integration of electric light and architecture between 1902 and the present day. PLDC Convention London.

Mitkiewicz, L. 1939. Kauno atsiminimai 1938-1939. Vilnius: Baltos lankos.

Marinetti, T. 1909. Manifesto del futurizmo, Le Figaro, 1.

Neumann, D. 2007. Nocturnal Modernity: luminous Architectures and the Avant - Garde. Bologna Editrice Compositori. Rassegna.

Neumann, D. 2002. Architecture of the Night - The Illuminated Building. Prestel. 78 p.

Razauskas, R. 2007. Kada atsirado gatvè, Transporto pasaulis 1(73): 30-33.

Schivelbusch, W. 1988. Disenchanted Night. Berkeley: University of California Press. 
Scheerbart, P. 1914. Glasarchitektur. Berlin: Gebr. Mann Verlag, 2000.

Stewart, J. A. 2001. Paul Scheerbart, The Gray Cloth. MIT Press. 143 p.

Teichmüller, J. 1927. Lichtarchitektur. Licht und Lampe.

Thiekotter, A. 2007. Bologna Editrice Compositori, in Lights wills through all space, and comes alive in crystal, Bruno Taut's glass Pavilion, Cologne 1914/Rassegna, 46-58.

Vyšteinaitè, M. 2003. Rietavo aukso amžius, Žemaičiu žemès 2: 18-19.

Ward, J. 1963. Weimar surfaces: urban visual culrure in 1920s Germany. University of California Press. 358 p.

Werner, O. 2002. Light Architecture; A New Term's Genesis Architecture of the Night - The Illuminated Building. München: Prestel. 28 p.

\section{LIGHTING AS A SYMBOL OF MODERN ARCHITECTURE}

\section{Valevičius}

Abstract. The paper is designed to reveal the aesthetics of artificial lighting and its influence on the architecture of the 20 th century. The main topics discussed are electric lighting, which appeard in our history at the end of the 19th century, and the technical development of lighting till the middle of the 20th century. Connections of artificial lighting with visual arts, its influence on advertisement, building architecture and the whole city are analysed. An idea is proposed that although lighting by nature was purely functional, very soon it acquired symbolic ambitions to represent architecture. In modern times architects understood that lighting was both a technological development and a symbol of a new era, when there appeared an independent field of creation - lighting architecture.

Keywords: artistic, artificial, electric lighting; glass, light architecture; modernity.

\section{MARTYNAS VALEVIČIUS}

Master, doctoral student, Dept of Fundamentals and Theory of Architecture, Vilnius Gediminas Technical University (VGTU), Pylimo g. 26/Traku g. 1, LT-01132 Vilnius, Lithuania.

E-mail:martynas@valevicius.com

Doctoral student, VGTU, 2005. Master of Architecture, VGTU, 2004. Bachelor of Architecture, Vilnius Academy of Fine Arts, 2001. Probation: Nordregio (2002); Universita degli studi di Firence (2003 -2004). Conferences: participant of 3 international conferences (2006). Research interests: night townscape, urban lighting, perception and formation of nightscape. 